generalize results from one laboratory to another, our results indicated the need for a note of caution. This is particularly true if one also considers that any one of these cultures may show several forms of sensitivities to $\mathrm{X}$-rays and ultra-violet light, depending on the growth medium and other factors ${ }^{5}$. The cultures used in this work were not pre-selected for heterogeneity. They were chosen because they were readily available. It is likely that other groups of $B / r$ cultures from other laboratories would be equally heterogeneous. Greater attention to the techniques of maintaining cultures and periodic checking of culture characteristics may allow a more meaningful correlation of the results obtained in different laboratories. We suggest that the designation $E$. coli $B / r$ be reserved only for cultures having all the characteristics originally observed by Witkin.

Howard I. ADLER

SARA D. HASKINS

Biology Division,

Oak Ridge National Laboratory, Oak Ridge, Tennessee.

Witkin, E. M., Proc. U.S. Nat. Acad. Sci., 32, 59 (1946).

${ }^{2}$ Witkin, E. M., Genetics, 32, 221 (1947).

${ }^{3}$ Morse, Y. L., and Carter, C. E., J. Bacteriol., 58, 317 (1949).

${ }^{4}$ Harold, F. M., and Ziporin, Z. Z., Biochim. Biophys. Acta, 28, 482 (1958).

${ }^{5}$ Stapleton, G. E., and Engel, M. S., J. Bacteriol. (in the press).

\section{Chitin Breakdown of Rhizosphere Bacteria}

BENFCKEl was the first to isolate chitinovorous bacteria from Kiel harbour. Since then much work has been done on microbiological breakdown of chitin. Micro-organisms producing chitinase have been observed in fresh and salt waters, in various kinds of soils, in plants and animal bodies, both living and decomposing. It has been reported that pathogenic micro-organisms also break down chitin.

I have studied whether bacteria living in the rhizosphere of superior plants are capable of attacking chitin.

For this purpose chitin has been prepared from the wing-cases of Melolontha melolontha L. with the Zechmeister procedure applied also by Gehring2. The native chitin obtained in this way was suspended in medium according to Bucherer ${ }^{3}$. The chitin was present in the medium as the sole source of carbon and nitrogen in amounts of $0 \cdot 1,0 \cdot 25$, and 0.5 per cent. Dipotassium hydrogen phosphate and magnesium sulphate $(0.03$ or 0.1 per cent $)$ were added. The solid medium contained 2 per cent washed agar. In all cases the $p \mathrm{H}$ was 7 .

Bacteria were isolated on chitin agar and meat agar plates from the rhizospheres of winter wheat (Triticum vulgare), sugar-beet (Beta vulgaris saccharifera), and false acacia (Robinia pseudoacacia) with Tepper's ${ }^{4}$ successive washing method (from the dilution of washed and triturated root). About 20 per cent of the bacterial colonies grown on meat agar, tested on both solid and liquid media, proved to be chitinivorous.

The bacterial colonies grown on chitin agar did not show a great variety of types, but the number of indi. viduals was rather high. Their total reached several hundred thousands per $1 \mathrm{gm}$. of washed root.

From the chitinivorous rhizosphere bacteria of winter wheat and false acacia a rod-shaped, most frequently occurring, active chitinivorous organismone from each-was selected. These retained their capacity of breaking down chitin for rather a long time.
These bacteria were subjected to detailed examination. In addition to them the capacity of breaking down the chitin of rhizosphere bacteria isolated on non-chitinous media by other workers was also studied: none of the five Pseudomonas strains belonging to various serological groups, grown from the rhizosphere of flax by Lovrekovich ${ }^{5}$, tested with the method described above, was found to decompose chitin. Out of the sixteen Bacterium strains grown from sugar-beet, Gyurkó subjected to detailed physiological examination five strains proved to be chitinivorous and the strains kept on meat agar have preserved this property for more than two years.

I wish to thank my colleagues, L. Lovrekovich and P. Gyurkó, for the strains examined. KeCskés MiháLx

Research Laboratory for Soil Biology,

Hungarian Academy of Sciences, Sopron.

1 Benecke, W., Bot. Z., 1, 227 (1905).

2 Gehring, H., Zbl. Bakt., 2, 108, 232 (1954).

3 Bucherer, H., Zbl. Bakt., 2, 20, 93 (1936).

4 In Fjodorov, M. V., Mikrobiol. gyak., Budapest, 166 (1952).

5 Lovrekovich, L., MTA, Agrártud. Közl., 15, 4, 413 (1959).

6 Gyurkó, P., Acta Agr. Hungaricae, 10, 1, 175 (1959).

\section{VIROLOGY}

\section{Influenza Virus Sialidase}

THe sialidase of influenza virus has been investigated quantitatively using the method recently described by Warren ${ }^{1}$ for determining free sialic acid in the presence of the compound bound to mucoprotein substrates. For this work, the substrate used was a mucoid derived from the nest-cementing substance of the swiftlet (Collocalia sp.). The crude material, available as Chinese 'edible birds' nest', was extracted with water at $60-65^{\circ}$ to yield a product which contained 10 per cent acid-hydrolysable sialic acid and which in high titre inhibited the agglutination of chicken erythrocytes by 'indicator' virus. Active virus was sedimented from freshly gathered chorioallantoic fluid by centrifugation at $35,000 \mathrm{~g}$ for $90 \mathrm{~min}$. The virus pellet was re-suspended in water to a volume $1 / 50-1 / 100$ that of the original fluid, effecting thereby a corresponding increment in hæmagglutinin titre as well as separation of virus from interfering chromogens present in chorioallan. toic fluid.

Aliquots of virus ( $A 2 / \mathrm{Japan} / 305 / 57$ ) representing a six-fold concentration of infective chorioallantoic fluid were mixed with substrate in phosphate $(M / 15)$ buffers, $p H 4 \cdot 0-7 \cdot 8$, at $37^{\circ}$, in the proportion $10 \mu \mathrm{gm}$. viral nitrogen to $1.4 \mathrm{mgm}$. substrate. Samples were removed at $10-\mathrm{min}$. intervals from 0 to $50 \mathrm{~min}$, and were immediately heated to $75^{\circ}$ for $10 \mathrm{~min}$., a temperature found to inactivate the virus completely. All samples were either stored frozen or at $4^{\circ}$ prior to being analysed simultaneously for sialic acid. Virus alone and solutions of substrate at each $p \mathrm{H}$, after incubation and heating to $75^{\circ}$ for 10 min., showed no free sialic acid. The most rapid evolution of chromophore due to enzyme occurred at $p H$ $5 \cdot 3$ and $6 \cdot 1$. These values probably encompassed the $p \mathrm{H}$ optimum for this strain, as the enzymatic release of sialic acid at $p \mathrm{H} 4 \cdot 0,7 \cdot 0$ and $7 \cdot 8$ was significantly slower (Fig. 1A). Closely similar results were obtained with three other strains of virus ( $N W S$, $F M 1$ and $P R 301$ ) and are therefore not given in 